\title{
Effects of Imprisonment on Self-Esteem Among Female Inmates in Selected Prisons in Kenya
}

\author{
Kamoyo, J.M \\ Department of Education, Chuka University, Chuka, Kenya
}

Doi:10.19044/esj.2018.v14n17p165 URL:http://dx.doi.org/10.19044/esj.2018.v14n17p165

\begin{abstract}
This study examined the effects of imprisonment on self-esteem among female inmates in selected prisons in Kenya. Descriptive survey design was adapted by this study. A total of 295 respondents formed the survey sample, comprising of 291 female inmates' and four (4) prison staff. Simple random sampling and purposive sampling methods were used to select the respondents. The study utilized questionnaires, interview schedules and an observation guide as instruments for data collection. Piloting was conducted in one selected prison to enable the researcher to improve on the reliability and validity of the instruments. Reliability of the instruments was estimated using Cronbach alpha coefficient. The instruments yielded a reliability coefficient of 0.857 which was considered appropriate for the study. Descriptive and inferential statistics were used for data analysis. The study found that there was significant relationship between imprisonment and inmate's self-esteem. The study established that most women in prison had low to moderate self esteem such that inmates felt more worthless compared to other people ever since they were imprisoned. The study recommended the need to for prisons come up with rehabilitative programmes employing self esteem strategy to improve on inmates self esteem.
\end{abstract}

Keywords: Imprisonment, Self-Esteem, Female Inmates

\section{Introduction}

Self-esteem is a psychological concept which refers to the evaluation an individual makes in relation to themselves and indicate the extent to which they see themselves and capable and worthy (Coopersmith, 1967). As such, self-esteem is the subjective emotional response that an individual has towards themselves. Psychologists usually regard self-esteem as an enduring personality characteristic, though normal, short term variations occur. Selfesteem is a concept of personality. For it to grow we need to have self-worth, and this self-worth will be sought from embracing challenges that result in 
the showing of success. Women are typically the primary care of their children, and at least one third of mothers are lone parents before imprisonment (Amanda, 2008), which inevitably disrupt the family unit. Research has found that $66 \%$ of women have dependent children under 18 , $34 \%$ have children under 5 and $40 \%$ have children aged between five and ten (Home office research study as cited by Amanda, 2008). When mothers are sent to prison, substitute childcare is of upmost importance (Morris, 1991). If relatives or friends are unable to take guardianship, the child will enter the care system, preventing barriers for mothers to regain potential rights on release (Dodge and Pogrebin, 2001). The loss of the mother role is considered as significant pain of imprisonment for women and can leave women with loss of identity and low self-esteem (Corston report as cited by Amanda, 2008).

Prisoners are denied basic privacy rights and lose control over the most ordinary aspects of their day-to-day existence. Inmates live in small sometimes extremely cramped and deteriorating spaces. The degraded conditions under which they live serve as constant reminders of their compromised social status and their stigmatized social role as prisoners. A diminished sense of self-worth and personal value may result in extreme cases of institutionalization; prisoners' internalize the symbolic meaning of externally imposed substandard treatment and degraded circumstances. Prisoners may come to think of themselves as the kind of people who deserve no more than the degradation and stigma to which they have been subjected while incarcerated and carry this degraded sense of self with them upon the release. Women once incarcerated, are subjected to procedures that cannot only be argued as being sexual in nature, but which also violates the prescribed norms of modesty of women by stripping them naked. Many women prisoners in Queensland prison have reported experiencing a sense of helplessness every time they are strip-searched (Bagdanic, 2013), because they resist the search, their clothes can be forcibly removed and they can be punished for resisting a search (Simmering and Diamond as cited by Bagdanic, 2013). For these reasons, some women may experience stripsearches as deeply humiliating, loss of self-esteem and a violation of their body (Bagdanic, 2013). In a study where interviews were conducted with fourteen women who were strip-searched, it was concluded that stripsearches can be damaging to women's self-esteem, psychological well-being and security (UCASS as cited by Bagdanic, 2013). Not only were strip searchers experienced as extremely humiliating by some women, but the feelings of anger, low self-esteem and fear of authority remained with many women long after the process of strip-searching was over (UCASS, as cited by Bagdanic 2013). 
Self-esteem has been the focus of many research studies, arguably to the point of exhaustion (Greenberg, Solomon, Pyszczynski, Rosenblatt, Builing, Lyon, Simon, Pinel, 1992). The field of psychology has theoretical models and frameworks for the purpose of self-esteem (Leary \& Baumeister, 2000) the consequences of self-esteem (Crocker, Lee \& Park, 2003), and the contingencies of self-esteem (Crocker \& Wolfe, 2001). Even in the midst of this accumulated knowledge on the topic, a sizeable gap exists, which leads to the question. "What about self-esteem in incarcerated women?" the majority of self-esteem researchers have studied college students' samples and developed theories (Rocker, et al, 2003). Thus, theories do not take into consideration the continuation of development throughout the lifespan and how life circumstances of later adulthood and imprisonment may not be explored within the theory. Scholars' points out that enhanced levels of selfesteem are associated with good health and ability to cope effectively in adverse circumstances; whereas low self esteem may result in psychological distress, depression, and anti-social behavior (Battle, 1990). Therefore this study sought to understand the relationship between imprisonment and selfesteem among female inmates in the context of selected female prisons in Kenya.

\section{Objectives}

The objective of this study was to establish the relationship between imprisonment and self-esteem among female inmates in selected prisons in Kenya.

\section{Methodology}

The study employed the descriptive survey research design. A sample of 291 female inmates and 4 prison wardens from 4 selected prisons participated in the study. The selection of the prisons and inmates who participated in the study was done using simple random sampling. The inmates were distributed among the 4 selected prisons using proportionate sampling. The prison wardens were purposefully selected. The total number of study participants was 295. Data from the sampled subjects was collected by use of questionnaires, interview guides and observation schedules. The questionnaires were used to collect data from the respondents. The rationale of using questionnaires is due to the large numbers of inmates. The Interview schedules were used to gather in depth information from the prison wardens. Observation schedules were used to supplement the information gathered from the respondents through questionnaire and interview guides. A pilot study was conducted in one prison with similar characteristics but not included in the study prisons. The data from the pilot study was used to compute the reliability of the instruments using Cronbach's Alpha 
Coefficient. The items were considered reliable if they yielded a reliability coefficient of 0.07 and above. In this study the reliability coefficient was 0.857. Quantitative data was coded, entered into the computer and analyzed by use of inferential and descriptive statistics with the aid of the Statistical Package for Social Sciences (SPSS) version 19.0. Qualitative analysis was done by determining patterns and trends from the information gathered through interviews and observation methods. Eventually, the data analysis results were represented on tables and by prose narrations.

\section{Results of the Study}

The study was set to test whether there were significant differences between imprisonment and self esteem among female inmates in selected prisons in Kenya. Information was obtained from 291 female inmates and 4 prison wardens and the data analysis generated the following results:

\section{Demographic Characteristics of the Respondents}

Majority of the inmates comprising $46.4 \%$ were below 30 years old while $45.6 \%$ were aged between 31 years and 50 years. A large proportion of the female inmates constituting $48.4 \%$ were single, $30 \%$ were married, $9.2 \%$ were widowed while $12.4 \%$ were divorced. Most of the female inmates $(54.8 \%)$ had between 1 to 3 children, $34.8 \%$ had 4 or more children while $10.4 \%$ were child free. Regarding the female inmates' highest level of education, $55 \%$ had primary school education certificates, $29.3 \%$ had secondary school education certificates, $3.2 \%$ had bachelor's degree, $2 \%$ had attended college while $10.4 \%$ had never attended school. Majority of the inmates $44.8 \%$ had served less than one year in prison, $20.4 \%$ had served between 1 and 2 years, $16.4 \%$ had served between 3 and 5 years, 11.2\% between 6 and 10 years while $7.2 \%$ had served for more than 10 years. Information was sought about the female inmates' religious affiliation and the data analysis results indicated that $54.8 \%$ were Protestants, $37.34 \%$ were Catholics while $10.4 \%$ were Muslims. Majority of the prison wardens comprising $75 \%$ were female while $25 \%$ were male with $50 \%$ being in the age bracket 30 years to 45 years. Regarding the work experience, $50 \%$ of the wardens had worked for a range of 1 year to 10 years and the rest had a work experience of more than 10 years. Majority of the prison wardens $(75 \%)$ were in the rank of an inspector while $25 \%$ were in the rank of a corporal. Most (50\%) of the prison wardens were Protestants, $25 \%$ were Catholics and $25 \%$ belonged to the Muslim faithful. 


\section{Relationship between Imprisonment and Self-Esteem among Female Inmates}

To determine whether the effects of imprisonment on self esteem among female inmates were significant, Chi Square test was conducted on 13 test items rated on a 5 level likert scale where $5=$ Strongly Disagree, $4=$ Disagree, 3 = Undecided, $2=$ Agree and $1=$ Strongly Agree. All the 13 statements are negatively stated hence scored in a reversed order. Any statement with a mean score below 2.5 indicated high self-esteem and any statement with a mean score of 2.5 and 3.5 indicated moderate self-esteem while any score between 3.5 and 5 indicated low self-esteem. The results of data analysis were represented on Table 1 below.

Table 1 Chi-Square Test on the Relationship Between Imprisonment and Self Esteem Among Female Inmates in Kenya

\begin{tabular}{|c|c|c|c|}
\hline Statements & Chi-Square & Df & $\begin{array}{l}\text { Asymp. } \\
\text { Sig. }\end{array}$ \\
\hline $\begin{array}{l}\text { I feel more worthless compared to other people ever since I was } \\
\text { imprisoned }\end{array}$ & $63.560^{\mathrm{a}}$ & 4 & .000 \\
\hline I have lost confidence in myself since imprisonment & $47.920^{\mathrm{a}}$ & 4 & .000 \\
\hline I criticize myself for all my faults since imprisonment & $18.680^{\mathrm{a}}$ & 4 & .001 \\
\hline I feel I have no good qualities like other prisoners & $40.120^{\mathrm{a}}$ & 4 & .000 \\
\hline I feel that I am a total failure as a person since imprisonment & $63.000^{\mathrm{a}}$ & 4 & .000 \\
\hline $\begin{array}{l}\text { I feel that my future is hopeless and will only get worse ever } \\
\text { since I was imprisoned }\end{array}$ & $51.400^{\mathrm{a}}$ & 4 & .000 \\
\hline I feel quite guilty most of the time in prison & $87.680^{\mathrm{a}}$ & 4 & .000 \\
\hline $\begin{array}{l}\text { I do not feel valued and needed in society ever since I was } \\
\text { imprisoned }\end{array}$ & $39.200^{\mathrm{a}}$ & 4 & .000 \\
\hline I have lost confidence in myself ever since I was imprisoned & $80.912^{\mathrm{b}}$ & 5 & .000 \\
\hline $\begin{array}{l}\text { Relationship between imprisonment and self esteem among } \\
\text { female inmates in selected prisons in Kenya }\end{array}$ & $103.736^{c}$ & 50 & .000 \\
\hline
\end{tabular}

The information in Table 1 reveals that there is a significant relationship between imprisonment and self-esteem among female inmates. The results of chi-square test showed that the calculated p-value of relationship between imprisonment and self esteem (.000) is less than the set alpha value of 0.05 as a consequence the null hypothesis $\left(\mathrm{H}_{0} 1\right)$ was rejected. In other words, significant findings revealed that imprisonment was a significant determinant of the inmate's level of self-esteem. Thus, it was necessary to determine the trends of these effects. In this case, mean perceptions of the respondents and the Standard Deviations were computed. All the 13 statements are negatively stated hence scored in a reversed order. Any statement with a mean score below 2.5 indicated high self-esteem and any statement with a mean score of 2.5 and 3.5 indicated moderate selfesteem while any score between 3.5 and 5 indicated low self-esteem. The results of the analysis are presented in Table 2 
Table 2

Relationship between Imprisonment and Self-Esteem of Female Inmates in Prison

\begin{tabular}{|c|c|c|c|}
\hline Statements & $\mathrm{N}$ & Mean & $\begin{array}{c}\text { Std } \\
\text { Deviation }\end{array}$ \\
\hline $\begin{array}{l}\text { I feel more worthless compared to other people ever since I was } \\
\text { imprisoned }\end{array}$ & 250 & 2.70 & 1.543 \\
\hline I have lost confidence in myself since imprisonment & 250 & 2.87 & 1.585 \\
\hline I criticize myself for all my faults since imprisonment & 250 & 2.86 & 1.409 \\
\hline I feel I have no good qualities like other prisoners & 250 & 3.17 & 1.502 \\
\hline I feel that I am a total failure as a person since imprisonment & 250 & 3.11 & 1.475 \\
\hline $\begin{array}{l}\text { I feel that my future is hopeless and will only get worse ever since } \\
\text { I was imprisoned }\end{array}$ & 250 & 3.18 & 1.577 \\
\hline I feel quite guilty most of the time in prison & 250 & 2.64 & 1.405 \\
\hline $\begin{array}{l}\text { I do not feel valued and needed in society ever since i was } \\
\text { imprisoned }\end{array}$ & 250 & 3.28 & 1.459 \\
\hline I have lost confidence in myself ever since i was imprisoned & 250 & 3.18 & 2.027 \\
\hline I see making friends a very difficult thing in prison & 250 & 3.12 & 1.445 \\
\hline $\begin{array}{l}\text { I feel I do not have much to be proud of in life ever since } \mathrm{i} \text { was } \\
\text { imprisoned }\end{array}$ & 250 & 2.96 & 1.568 \\
\hline I feel I do not deserve love and respect since imprisonment & 250 & 3.50 & 1.498 \\
\hline I feel irritable all of the time since imprisonment & 250 & 3.00 & 1.541 \\
\hline effects of imprisonment on self esteem & 250 & 3.0440 & 1.03524 \\
\hline Valid N (listwise) & 250 & & \\
\hline
\end{tabular}

The mean analysis in Table 2 revealed existence of low self-esteem among female inmates as a result of imprisonment in selected prisons in Kenya. The means ranged from 2.64 to 3.50 out of a maximum score of 5 . Out of the thirteen statements on self esteem, five statements suggested low self-esteem among female inmates in prison. From the findings, feeling quite guilty most of the time for being in prison scored a mean of (2.64) and SD of (1.405) indicating low self-esteem. Feelings of worthlessness among inmates scored a mean of 2.70 and SD of 1.543 indicating moderate selfesteem among the female inmates. Tendency for the inmates to criticize themselves for all the faults since imprisonment scored a mean of 2.86 and SD of 1.409) indicating moderate self-esteem. Loss of confidence among inmates since imprisonment scored a mean 2.87 and SD of 1.585 indicating moderate low self-esteem. I feel I do not have much to be proud of in life ever since I was imprisoned scored a mean of 2.96 and SD of 1.568. The overall mean was 3.0440 with a SD of 1.03524 , out of the maximum mean score of 5 points. Findings from the in-depth interviews with the prison staff were in agreement with the findings from the prisoners that there was a significant relationship between imprisonment and self esteem. 


\section{Discussions}

Findings in this study revealed that imprisonment had a direct effect on inmates self esteem. The effect according to the data is moderate. Inmate's response item with the lowest mean score was 2.64 with SD of 1.405. This implies that most of the inmates were guilty most of the time in prison. The findings are consistent with the research results of Bagdanic (2013) who found that many women prisoners in Queensland prison experienced a sense of helplessness every time they are strip-searched and because they resist the search their clothes are forcibly removed punished for resisting a search. For these reasons, some women may experience stripsearches as deeply humiliating, loss of self-esteem and a violation of their body. As noted from this study Low self-esteem reduces a woman's ability to cope. It increases the self-destructive behaviors such as slashing themselves with razors, knives or other sharp items. Moreover, the findings are consistent with John Howard Society of Alberta (1999) which indicated that $59 \%$ of the female inmates engaged in self- injurious behaviors.

Feelings of worthlessness were evident from this study. A large portion of the inmates had a feeling that they were worthless compared to other people ever since they were put into prison. This in turn affected their psychological well-being. In support Emeka (2009) asserts that imprisonment is seen as an extremely painful experience that leaves an emotional scar on the victim, resulting to negative image of self among the female inmates. Self-esteem is said to be significantly related to quality of life and physical as well as mental well being (Witmer \& Sweeney, 1992).

Myers (2002) points that low self esteem may lead to increased risk of depression, drug use and some form of antisocial behavior among inmates. Inmates in this study revealed that they did not have much to be proud of in life ever since they were imprisoned. The mean score for this response was 2.96 with a SD of 1.568. This Reflected moderate self esteem among the female inmates. One of the reasons that could have contributed to this is the many reforms that the government has implement in all the prisons in the country.

The findings from the open ended items, interviews and observations demonstrate that inmates suffer from low to moderate self- esteem as a result of imprisonment. Inmates in their written narrations expressed concern on the kind of treatment from the prison staff. They said that prison staff treat them with disrespect and talk rudely to them. This form of degradation make inmates to view themselves as people who do not have value in society hence low self esteem. Igomu (2013) states that prisoners, particularly female inmates suffer from stigma and low self esteem while in prison and after release to society. In other words, significant findings revealed that imprisonment was a significant determinant of inmate's level of self esteem. 
Government and especially, counselors and prison officers should be aware of the connection between imprisonment and self-esteem in inmates. If inmates develop higher levels of self esteem, they would exhibit higher social and personal responsibilities. This calls for Practical research to develop and assess programmes for prison officers and counselors in the use of self-esteem as strategies for rehabilitative counseling for inmates.

\section{Conclusion}

The main aim of the study was to establish the effects of imprisonment on self esteem among female inmates in selected prisons in Kenya. This study found out that imprisonment had significant impact on self-esteem among female prisoners. Based on this, government and prison authorities need to develop gender specific programmes to help inmates minimize prison hardships and at the same time preparing them to join the wider society after release. According to the study inmates felt depressed for being alienated from their loved ones particularly separation with their children and the significant others. Prison should continue with the open door policy such that prisoners are allowed more time to interact with their loved ones possibly two to three times in a week to reduce the effects of social gap.

From the findings, imprisonment was found to impact significantly on inmate's level of self esteem. As a result of this, prison authorities, counselors and other partners should be aware of the link between imprisonment and self-esteem among female inmates. The loss of the mother role is considered as significant pain of imprisonment for women and can leave women with loss of identity and low self-esteem. This is key if prisons have to be seen living to their mandate of rehabilitating inmates for easy integration into society after release.

\section{Recommendations}

Rehabilitative programmes employing self esteem strategy should be carried out in prisons to improve on inmates self esteem. This is because the study established low self esteem among inmates owing to imprisonment.

The prison environment could also be modified to allow for more social support groups and home like environment where female inmates may nurture a sense of belongingness especially those serving long sentences.

\section{References:}

1. Amanda, M. (2008). Women in Prison; A Review of Current Prison System; Future Directions and Alternatives. Dissertation, Nothingham Trent University Internet Journal of Criminology.www.internet journal of criminology. Com 
2. Battle, J. (1990). Self-Esteem; The New Revolution. Edmonton, Alberta, Canada: James Battle \&Associate

3. Bogdanic, A. (2013).Strip searching of Female Prisoners in Queensland.www.wipanall/Publication/bogdonic 2qid.pdf.

4. Coopersmith, S. (1967). The Antecendents of Self Esteem. San Fransisco; Freeman

5. Crocker, J. Lee, S. J., \& Park, L. E. (2004). The Pursuit of SelfEsteem; Implications for Good \& Evil in A.G. Miller (eds.), The Second Psychology Of Good and Evil (pp. 271-302). New York; Guilford Press.

6. Dodge, M. \& Pogrebin, M (2001). Collateral Costs of Imprisonment for Women Complications of Reintegration. The Prison Journal Vol81 (1) P; 42-5-4.

7. Emeka, A.N. (2009). Evaluating Self-Esteem among Inmates in Enugu Prison. Unpublished Doctoral Thesis University of Nigeria Nsukka.

8. Greenberg, J., Solomon, S., Pyszczynski, T., Rosenblatt, A., Builing, J., Lyon, D., Simon. L., \& Pinel, E (1992). Why Do People Need Self-Esteem? Converging Evidence that Self-Esteem Serves an Anxiety-Buffeing Function. Journal of Personality and Social Psychology, 63, 913-922.

9. Igomu, A. C. \& Mayange, L.T. (2013). Relationship between SelfEsteem and Personal Development of Prison Inmates in Jilango, Taraba State Nigeria. Journal of Education and Practice Vol.4.No.4, 277-282.

10. John Howard Society of Alberta (1990). Effects of Long-term Incarceration on Female Inmates. http.

11. Leary, M. R., \& Bausmeister, R.F. (2000). The Nature and Function of Self Esteem, Sociometer Theory in Zanna, M.P, (Eds.), Advances in Experimental Social Psychology (pp. 1-62). San Diego: Academic Press.

12. Morris, A. (1991). Women Crime and Criminal Justice, oxford; Basil Black well.

13. Myers, D. G. (2002). Social Psychology ( $7^{\text {th }}$ Ed.) The McGraw-Hill Companies.

14. O'Connor, T. (2004). What Works, Religion as a Correctional Intervention: Part 1. Journal of Community Corrections 14 (1), 1127. 